\title{
木材チップの水輸送について
}

\author{
王子製紙株式会社 野田容道, 林 土光
}

\section{Pipe Line Hydraulic Transportation of Woodchips}

\author{
Masamichi Noda and Dokō Hayashi
}

Oji Paper Manufacturing Co., Ltd.

\section{1. 開発の端緒}

\subsection{PPRIC (Pulp and Paper Research}

Institute of Canada) の研究とその経過 木材チップのパイプライソによる水輸送について, 本格的なテスト研究を行なったのは, カナダの PPRIC が初めてであるとされている。

1957 年に開始し 1963 年にレポートの発表がなされ ている。それによると実用パイプライン計画としては, 管サイズは $6 \mathrm{~B}, 8 \mathrm{~B}, 10 \mathrm{~B}$ の各サイズのもの

体積濃度は 20 40\%

スラリー流速は $1.2 \sim 1,8 \mathrm{~m} / \mathrm{sec}$

の範团を選ぶことが適当であろらと結論づけているが その後 PPRIC ではチップの水輸送研究は打ら切って いる模様である。

\section{2 その他の動向}

一方 PPRIC の 1960 年のテスト結果発表に刺激さ れて，アメリカ，カナダはもとより，ソ連などでも色 々のテストが行なわれ，またチップ水輸送実用設備計 画などが発表されてきている。しかし，これらテスト 結果についてはいずれも詳細が発表されて括らず，ま た比較的小規模実験が多かったようである。

現在までのところチップの水輸送に関する実用ない しは半実用の設備はまだ世界中で建設された例はなく， 当社のチップ水輸送設備が稼働すれば，世界最初のも のになると見られる。

\section{2. 苫小牧工場における実用化試験}

\section{1 実用化の背景}

原材料不足の我が国紙パ産業においては，年々輸入 チップに依存する割合は大きい。当社もとの例外では ない。現在輸入チップは苫小牧港に陸揚げし，工場へ トラック輸送している。輸送距離は約 $3 \mathrm{~km}$ である。

将来輸送コストの高騰と交通公害の問題は避けるこ とができない。

そこで，これに代わる輸送方式を検討した。

先ず風送方式であるが，これは電力消費が莫大とな るばかりでなく，チップの細裂が進み長距離輸送には
適さない。

次にコンベャー方式であるが，市街地の通過には地 下埋設が必要となろら。この場合, 建設費が嵩むなど 短所が多い。

これらに較べ，水輸送はパイプの敷設ですみ，チッ プも傷まず，同時にチップの洗浄ができ，最も有利で あると判断し，実用化試験に踏及切ったものである。 実験は約 3 年の墄月と概算 1 億円の費用をついやした。

\section{2 実験設備概要 (図-1参照)}

混合設備より流出するチップスラリーは，ポンプを 経てパイプラインに送り达まれ, 循環テストでは混合 設備に，放流テストでは放流場に放出する配管とした。

パイプラインルは要所にアクリル管を挿入，流相観 察ができるようにし，パイプベンドRは種々のものを 取り入れ，最適 $\mathrm{R}$ の見極めを行なった。もらろん各所 に圧力計を設置した。チップは混合設備に定量供給で きる設備とし，また清水供給設備は言うまでもなく， 輸送物量は計画量を上回る実験を行ならなど，全て実 用設備に近いものとして実験を行なった。

\section{3 試験経過概要}

(1) 43 年度

小規模混合テスト

工業技術院公害資源研究所にて小規模実用化試験 苫小牧工場にて 8 B 40 mライン循環, 放流試験

(2) 44 年度

$6 \mathrm{~B} 300 \mathrm{~m}, 600 \mathrm{~m}, 1,200 \mathrm{~m}$ ライン循環, 放流試験

8 B $100 \mathrm{~m}, 200 \mathrm{~m}, 300 \mathrm{~m}$ ライン循環, 放流試験 混合設備, スラリーポンプの開発研究から始まり, 流 動現象，圧力損失，チップサイズと管径など上記パイ プラインルより実験積重ね。

(3) 45 年度

6 B $600 \mathrm{~m}$ ライン循環, 放流試験

8 B $300 \mathrm{~m}, 600 \mathrm{~m}$ ライン循環, 放流試験 樹種別, 管径の相異による特質, 長時間連続運転など の試験を上記パイプラインにて実施。

さらに, ラジオアイソトープ（RI）, 高速度カメラ 撮影による流動現象の追跡ならびに観察試験。

\section{4 試験結果の概要}




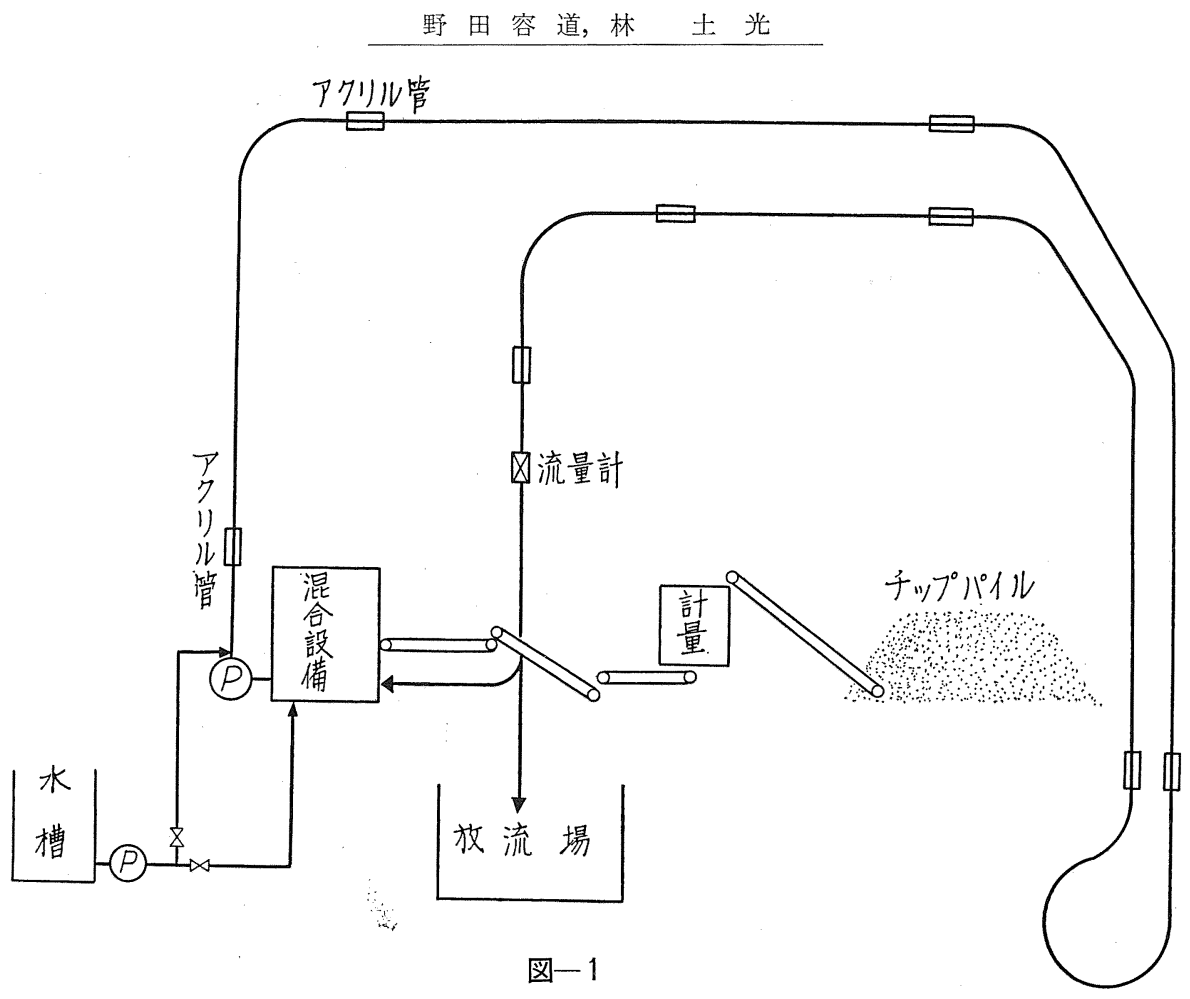

(1) 混合設備特よびスラリーポンプ

チップのポンプ輸送の前工程として特に大切なこと は, 濃度の均一化とェアーの混入防止を考慮した設備 とすることである。当社はその開発に成功した。

長距離輸送を考えた場合, そのスラリーポンプは, 高 揚程, 高効率化の要求は当然のすう勢である。某社と 共同研究を進め注満足の得られるポンプを開発した。 (2) スラリー流相 (図一2参照)

高流速での管中のチップを観察すると個々のチップ は乱れ動いて流れ，均一飞分散した乱流状態となる。 これを乱流または安定流と呼んでいる。

流速を徐々に下げると比重の重いものは沈降しょう とし，管上下に濃度の差が見られるようになる。この 状態を乱流と摺動流の中間と呼んでいる。

さらに流速を下げると上部に浮遊するものと，管底 を堆積捪動するものに分離し，管中央部が比較的薄く なる，これを摺動流と呼ぶ。

さらに下げると部分的に凝集し，流れ方向の濃淡が 現われる。これを部分流または山形流と呼んでいる。 これより流速を下げるとプラグ状となり，圧力損失は 急上昇し閉塞につながる。これを限界流と呼ぶ。

木材チップの実用流速は安定流域であることが望ま しい。カナダの文献に示された $1.2 \sim 1.8 \mathrm{~m} / \mathrm{sec}$ は濃 度との関係もあろらが, 当社の実験の結果と較べると, 低流速過ざるので，実用には適さない。
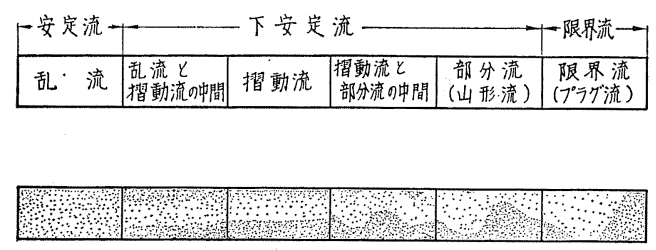

図一２ スラリー流相

（3）流速と压力損失の関係（図一 3 参照）

図の如く他の鉱涬スラリーと良く似ている。高濃度 ほど，圧力損失は増加し，輸送限界濃度は $C_{V}=35 \%$ \%位である。カナダ文献では $C_{V}=45 \%$ まで可能と言 っているが，この点については今もって疑問に思って いる。

ある流速以上になると, 清水の圧力損失より少なく なる点がある。

ある流速以下になると，急速に圧力損失が増大し， 閉塞する。

（4）管径と圧力損失の関係（図一 4 参照）

図は一定濃度に括ける相関関係を表わしている。 径の大さいもの程圧力損失は少ないが，同一流相とす るためには流速を上げなければならない。

径が小さい程圧力損失が大きいが，チップが浮流し 易いため，流速が下げられる。

（5）樹種別の特質（図一 5 参照） 


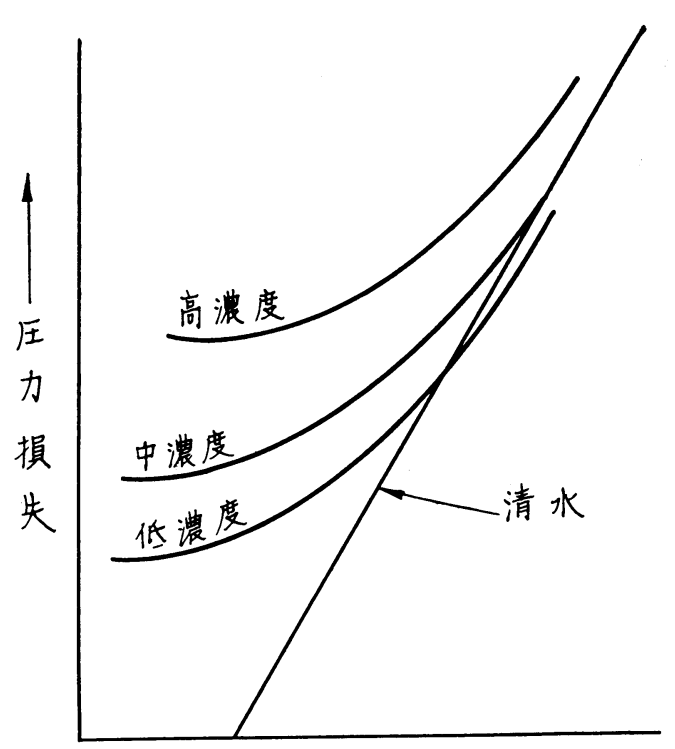

流速 -

图一３流速と圧力損失（ダクラスファー）

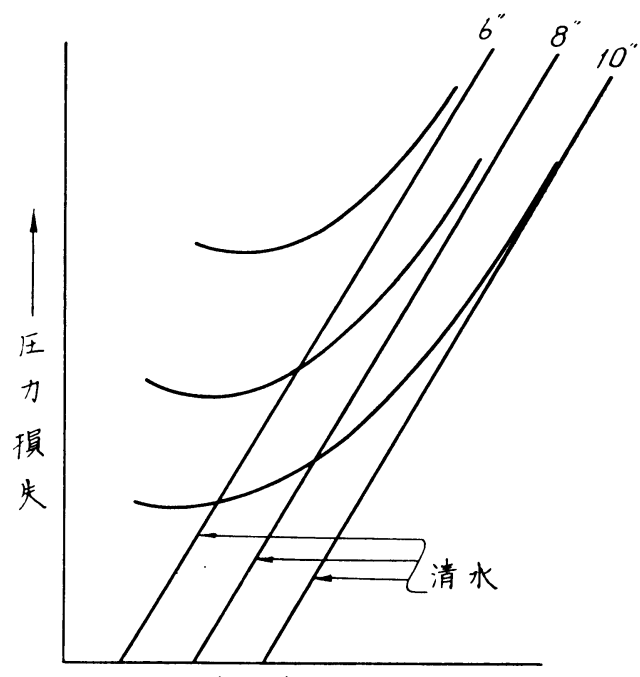

流速 $\longrightarrow$

図-4 パイプ径別流速と压力損失 (ダラスファー) 但し, 一定濃度

ダグラスファー, 北洋樹, 広葉樹の各樹種により相 違が見られる。

容積重の重い樹種ほど圧力損失も大きい。 チップ表面の平滑な樹種（広葉樹など）ほど㠜集の 度合いは少ないので部分流となりにくい。したがって 摺動流の領域が広い。

異樹種混合チップの安定流速は容積重の重いものに 左右される。

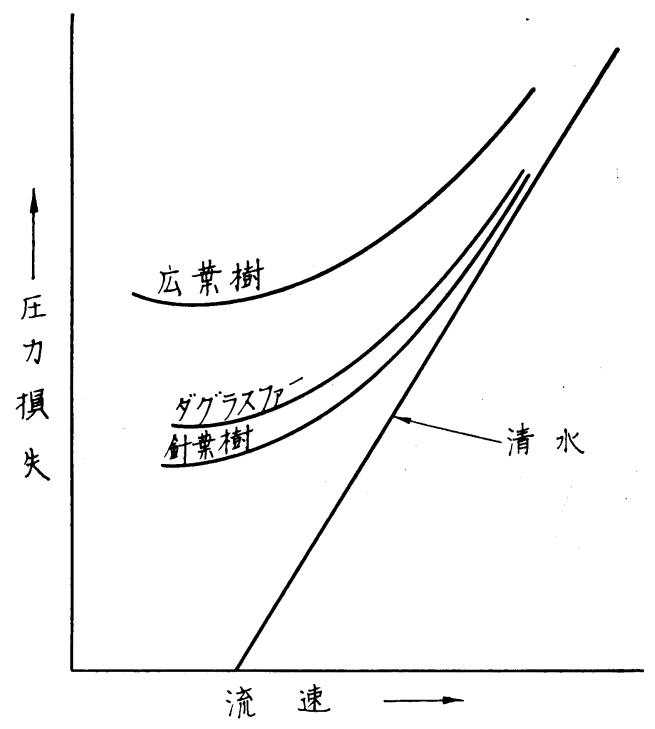

図一－＼cjkstart材種別流速と圧力損失（但し一定濃度）

(6) R I 試験

各流相に括ける管内チップの動向を知ることは，実 用化に当り必要なことである。例えばチップの速度と 水との間に速度差があるとして，さらにこの速度差が， 輸送距離と共に変化するようなことがあるとすれば, 長距離の間に管内の流相が変り，ひいては閉塞につな がるかも知れない。このような速度のずれはないのか ぞうかを確認する手段として，ラジオアイントープを チップに埋め込みその追跡実験を行なった。

実験の結果, 安定流であれば，水の平均流速よりも テストピース（チップ）の流速が速いことが判明した。 これは，チップが管中央部に集中して流れるため，水 の平均流速よりもチップが速いことになる。速度差は 一定であるから, この点からも, 安定流を得れば, 長 距離輸送に心配は無い。

（7）安全設備

最も重要なことは停電, 故障に備えて管内スラリー の処置をどうするかである。

種々実験の結果では，流れを停止させずすみやかに 清水もしくはェアーによって管外に排出洗管すること である。当社ではエアーパージテストを数多く行ない, 予想外の好結果を得たが，これは特殊バルブを開発し たためである。

なお，特殊バルブを含め数多くの特許を申請中であ る。

\section{3. 実用設備計画概要 (図一6参照)}

1. 亘長（港～工場間） $2,460 \mathrm{~m}$ （内社有地通過60\%） 


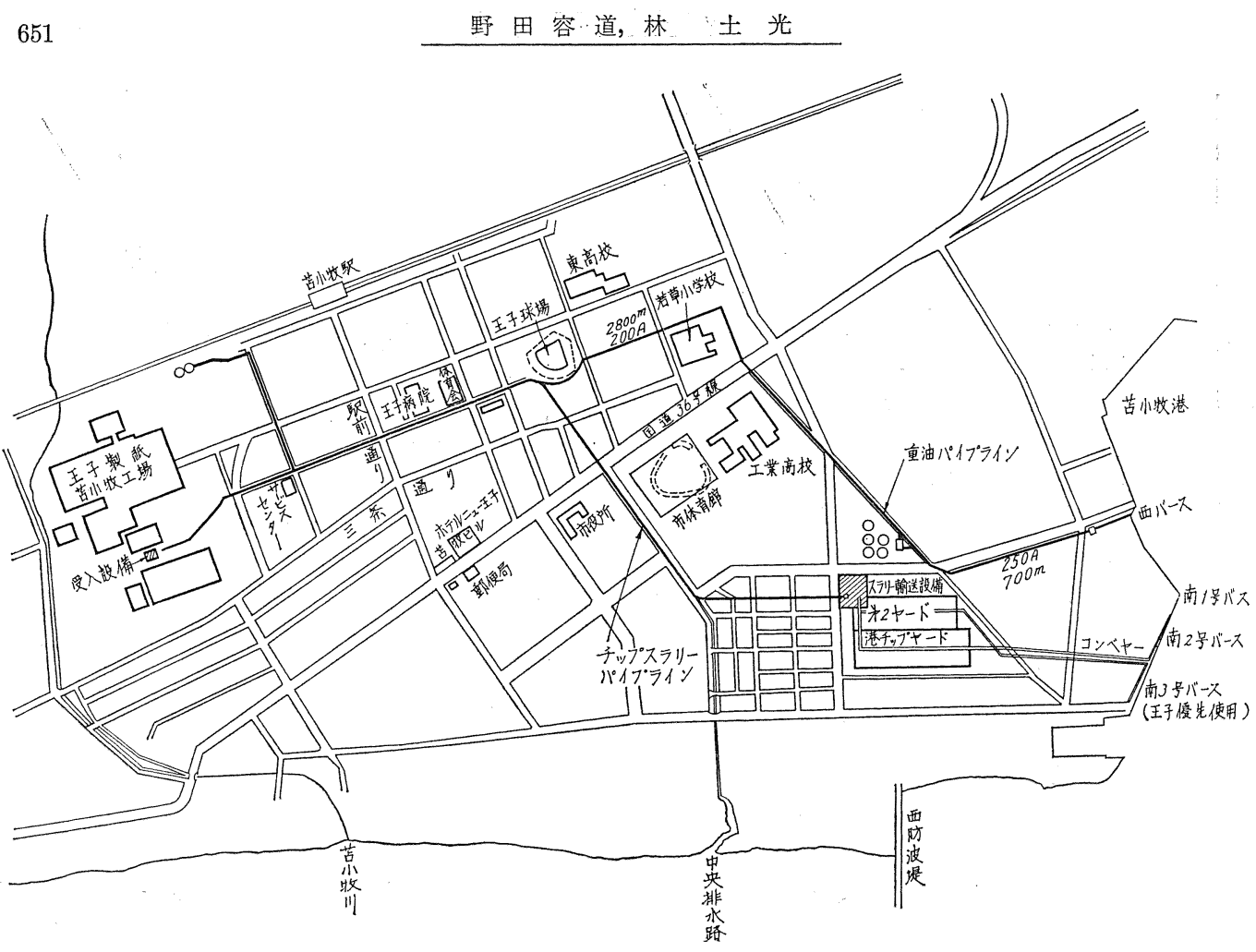

図一6 港・工場間チップ水輸送パイプライン（国道 36 号線以降工場間は殆ど社有地）
2. チップおよび清水供給設備 1 式
6. 脱水処理設備
1 式
3. スラリーパイプ
8 B圧力鋼管・ライ
7. 安全対策設備
1 式
4. 水パイプ
ニング
な特このチップ水輸送設備が完工すれば，既に港と
4. 水パイプ
$12 \mathrm{~B}$ 圧力鋼管・ライ
工場間に敷設されている重油パイプラインと共に, 苫
5. スラリーポンプ$$
\text { ニング }
$$
$2 \sim 3$ 台 直列
小牧工場の重要なる輸入原料資材の動脈となり，輸送 の近代化に大きな役割を果すものと期待される。

\section{0th Annual Meeting}

主催; Canadian Pulp and Paper Association 場所; Queen Elizabeth Hotel, Montreal 期間； 1 月 29 日 2 月 1 日，1974 年

ホテル予約先; the Room Division Manager, Queen Elizabeth Hotel, 900 Dorchester Blvd. West, Montreal, Que., Canada

論文照会先; R. A. Joss, Manager, Technical

Section, CPPA, 2300 Sun Life

Building, Montreal 110, P. Q. H3B $2 \times 9$

注）展示会は1974 年1月29日〜31 日に行なわれる 予定。

\section{Spring Corrugated Container Conference}

主催; Technical Association of the Pulp \& Paper Industry (TAPPI)

場所; The Marriott Hotel in New Orleans, Louisiana

期間；1974 年 6 月 4 日〜 6 月 6 日

参加費; 10 ドル

ホエル予約申込先; The TAPPI Preregistration Desk, One Dunwoody Park, Atlanta, Georgia 30341 U.S. A.

照会先; Mr. W.B. Manning, One Dunwoody Park, Atlanta, Georgia 30341, U.S. A 